\title{
Desain Pengembangan Kurikulum Pendidikan Agama Islam
}

\author{
Mahrus \\ Sekolah Tinggi Agama Islam Nahdlatul Ulama Malang, Indonesia \\ mahrus283@gmail.com
}

\begin{abstract}
Design can be formulated as a deliberate process of thinking, planning and selecting the parts, techniques, and procedures that set a goal. Challenges to Islamic religious education include a moral crisis and a personality crisis. Therefore, Islamic religious education is required to be able to equip students with the moral, personality, quality and maturity of life to live a multi-cultural nation life, which is currently hit by an economic crisis in order to live peacefully in the world community.

In an effort to develop an Islamic education curriculum to overcome various challenges and problems, it is necessary to pay attention to several aspects including strategies, methods, materials, Islamic religious teacher resources, facilities, teaching media and supporting instruments.

Taking into account the demands of the globalization era of Islamic religious education in madrasas and public schools, it is necessary to implement several strategies, including: First, perfecting the religious education curriculum so that the subject matter reaches a proportional and functional composition but does not burden students. Second, combining religious material with character education materials such as PPKn or other related subjects can also erode the dichotomy of knowledge. Third, creating a religious condition in the school environment
\end{abstract}

Keywords: Development Design, Curriculum, Islamic education

\section{Pendahuluan}

Pengembangan SDM pada hakikatnya merupakan upaya untuk mengaktualisasikan dan mengembangkan seluruh potensi manusia secara terpadu untuk mencapai kompetensinya sebagai subjek pembangunan sesuai dengan tuntutan zaman. Dalam hal ini disamping SDM dituntut untuk memiliki dan menguasai Iptek serta keterampilan professional agar memasuki jenis kerja. Juga diharapkan memiliki sikap mandiri, tegas, wawasan yang luas, berorientasi pada nilai-nilai moral serta bisa berpikir kreatif dan inovatif dalam menghadapi masa depan (Azyumardi Azra, 1999, p.13).

Semua program pendidikan di berbagai jenjang dan jenis pendidikan dirancang untuk mencapai tujuan pendidikan. Rancangan program pendidikan di setiap jenjang dan jenis pendidikan disebut dengan istilah kurikulum. Kurikulum adalah niat dan harapan yang dituangkan dalam bentuk rencana atau program pendidikan untuk dilaksanakan oleh guru di sekolah. Kurikulum merupakan salah satu alat untuk membina dan mengembangkan siswa 


\section{Mahrus}

menjadi manusia yang beriman dan bertaqwa kepada Tuhan Yang Maha Esa, berakhlak mulia, sehat, berilmu, cakap, kreatif, mandiri, dan menjadi warga Negara yang demokratis serta bertanggung jawab.

Kurikulum Pendidikan Agama Islam dirancang untuk mengantarkan siswa kepada peningkatan keimanan dan ketaqwaan kepada Allah SWT serta pembentukan akhlak yang mulia. Keimanan dan ketaqwaan serta kemuliaan akhlak sebagaimana yang tertuang dalam tujuan akan dapat dicapai Pendidikan Agama Islam dengan terlebih dahulu jika siswa memiliki pengetahuan dan pemahaman yang utuh dan benar terhadap ajaran agama Islam, sehingga terinternalisasi dalam penghayatan dan keasadaran untuk melaksanakannya dengan benar. Dengan demikian kurikulum dan pembelajaran PAI yang dirancang seharusnya dapat menghantarkan siswa kepada pengetahuan dan pemahaman yang utuh dan seimbang antara penguasaan ilmu pengetahuan tentang agama Islam dengan kemampuan pelaksanaan ajaran serta pengembangan nilai-nilai akhlakul karimah. Desain pengembangan kurikulum PAI harus betul-betul diperhatikan, lebihlebih dalam aplikasinya ketika proses belajar mengajar berlangsung. Selama ini paham dari kebanyakan masyarakat menganggap bahwa dengan kehadiran PAI disekolah diharapkan mampu membina keilmuan baik dari segi IPTEK maupun IMTAK peserta didi. Anggapan seperti ini harulah benar-benar diperhatikan karena kalau tidak akan berakibat fatal. Kita tahu pada saat sekarang ini peran PAI bukan hanya sekedar mengutamakan pendidikan agama saja tetapi lebih diharapkan ada perpaduan antara pendidikan umum dengan pendidikan agama.

Guru PAI merupakan salah satu faktor yang mempengaruhi kualitas pembelajaran pendidikan agama islam. Faktor lain yang mempengaruhi pembelajaran PAI adalah siswa. Dengan demikian, komponen dan desain kurikulum sangat mempengaruhi dalam proses belajar mengajar. Namun, betapapun bagusnya kurikulum yang telah dibuat, hasilnya tergantung pada guru yang mengajarkannya di dalam kelas.

\section{Pembahasan}

\section{Pengertian Desain Pengembangan Kurikulum}

Desain dapat dirumuskan sebagai proses yang disengaja tentang suatu pemikiran, perencanaan dan penyeleksian bagian-bagian, teknik, dan prosedur yang mengatur suatu tujuan. Desain kurikulum dapat didefinisikan sebagai rencana atau susunan dari unsur-unsur kurikulum yang terdiri atas tujuan, isi, pengalaman belajar dan evaluasi (Oemar Hamalik, 2007, p.194). 
Salah satu krakteristik penting dari kurikulum adalah konseptualisasi dan organisasi berbagi bagian dari kurikulum tersebut.

Fred Percifal dan Henry Ellington (1984) mengemukakan bahwa desain kurikulum adalah pengembangan proses perencanaan, validasi, implementasi, dan evaluasi kurikulum. Saylor mengajukan delapan prinsip sebagai acuan dalam mendesain kurikulum sebagai berikut.

a. Desain kurikulum harus memudahkan dan mendorong seleksi serta pengembangan semua jenis yang esensial bagi pencapaian prestasi belajar, sesuai dengan hasil yang diharapkan;

b. Desain memuat berbagai pengalaman belajar yang bermakna dalam rangka merealisasikan tujuan-tujuan pendidikan;

c. Desain harus memungkinkan dan menyediakan peluang bagi guru untuk menggunakan prinsip-prinsip belajar dalam memilih, membimbing, dan mengembangkan berbagai kegiatan belajar di sekolah;

d. Desain harus memungkinkan guru untuk menyesuaikan pengalaman dengan kebutuhan, kapasitas dan tingkat kematangan siswa;

e. Desain harus mendorong guru mempertimbangkan berbagai pengalaman belajar anak yang diperoleh di luar sekolah dan mengaitkannya dengan kegiatan belajar di sekolah;

f. Desain harus menyediakan pengalaman belajar yang berkesinambungan, agar kegiatan belajar siswa berkembang sejalan dengan pengalaman terdahulu dan terus berlanjut pada pengalaman berikutnya.

g. Kurikulum harus didesain agar dapat membantu siswa mengembangkan watak, kepribadian, pengalaman, dan nilai-nilai demokrasi yang menjiwai kultur; dan

h. Desain kurikulum harus realistis, layak, dan dapat diterima (Oemar Hamalik, 2007, p.194195).

\section{Komponen Pengembangan Kurikulum Pendidikan Agama Islam}

Desain pengembangan kurikulum bertujuan untuk membuat proses, implementasi, dan pengawasan (monitoring) kurikulum agar lebih mudah dikelola. Kegiatan ini terdiri dari 9 komponen yaitu (Oemar Hamalik, 2007, p.197-201):

1. Kebijakan umum dalam kegiatan belajar-mengajar

Kebijakan di sini didefinisikan sebagai pelatihan atau metode kegiatan yang telah dipilih baik oleh lembaga, kelompok, atau individu dari sekian alternatif yang ada, dan dalam 


\section{Mahrus}

kondisi yang diberikan untuk membantu dan menentukan keputusan saat ini dan di masa depan.

Kebijakan umum dalam belajar-mengajar dibuat berdasarkan aspek-aspek tertentu yang memberikan jawaban atas pertanyaan spesifik berikut:

a. Apa pengalaman belajar yang diinginkan siswa? Apa yang kita inginkan dari siswa ketika mereka berada dalam proses belajar?

b. Apa yang menjadi ciri khas lingkungan belajar? Bagaimana lingkungan fisik yang menunjang dalam kegiatan belajar-mengajar? Dalam mengorganisasikan kelas, apa yang ingin dijelaskan tentang hubungan antara siswa dengan siswa atau antara guru dengan siswa?

c. Apa yang menjadi karakteristik kemampuan guru dalam mencapai kualitas pengalaman mengajar yang diinginkan?

\section{Program kegiatan}

Strategi program kegiatan digunakan untuk memfasilitasi implementasi kebijakan dan monitoring. Tujuan dari program ini adalah memfasilitasi implementasi oleh pengambil satu kebijakan dan membuatnya fokus pada seluruh kegiatan sekolah selama periode kegiatan belajar.

3. Rencana pengembangan sekolah

Rencana pengembangan sekolah berhubungan dengan kebijakan belajar-mengajar dan program kegiatan yang merupakan prioritas utama. Oleh karena itu, diharapkan adanya program kegiatan yang berkenaan dengan kebutuhan perencanaan pengembangan sekolah.

4. Organisasi dan struktur kurikulum

Struktur dan organisasi dokumen kurikulum menampilkan respon sekolah sebagai berikut:

a. Jumlah waktu yang ditetapkan dalam perbedaan atau kombinasi subjek. Analisis waktu ini harus dilakukan secara hati-hati.

b. Bagaimana perbedaan subjek diterapkan dalam organisasi kurikulum.

c. Bagaimana memutuskan struktur kurikulum yang telah disetujui untuk disebarkan kepada guru.

5. Skema kerja

Skema kerja mempresentasikan apa yang telah dibuat dalam penentuan keputusan tentang struktur dan organisasi kurikulum. Setiap skema harus merefleksikan fakta bahwa pada 


\section{Desain Pengembangan Kurikulum}

Pendidikan Agama Islam

masa ini siswa harus mempunyai kemampuan yang progresif dan memahami sistem informasi.

6. Penilaian, perekaman, dan pelaporan

Komponen keenam ini terdiri atas keseluruhan kebijakan sekolah untuk penilaian, perekaman, dan pelaporan perkembangan siswa. Banyak sekolah yang memiliki koordinator penilaian sendiri, yang menjadi kunci utama dalam kegiatan penilaian. Koordinator kurikulum harus dapat berkomunikasi yang baik dengan koordinator penilaian, agar dapat menghasilkan dokumen kebijakan yang efektif yang mengindikasikan bagaimana penilaian akan diambil dalam berbagai kajian kurikulum.

7. Petunjuk teknis

Petunjuk teknis atau "guidelines" berfungsi dalam menjawab pertanyaan "bagaimana". Pembuatan guidelines bertujuan untuk memberikan respon pertama pada pertanyaan yang muncul. Arsip guidelines tersebut kemudian didokumentasikan untuk membantu memudahkan guru dalam proses belajar-mengajar.

8. Perencanaan jangka pendek dan menengah

Perencanaan jangka pendek dan menengah sering digunakan kelompok tim tahunan, yang didukung oleh manajer mata pelajaran. Skema ditransfer dalam suatu rencana detail yang mempunyai tujuan belajar yang luas, sumber diidentifikasi serta dialokasikan, dan dikonfirmasi diabuat agar kurikulum dapat diorganisasi dalam kurun waktu tertentu yang disetujui. Perencanaan jangka pendek dan menengah telah ditetapkan berdasarkan proporsi tertentu agar terjadi keseimbangan antara kerangka kerja jangka pendek dengan kerangka kerja yang lebih detail.

9. Strategi monitoring

Komponen ini adalah komponen terakhir desain penngembangan kurikulum. Outline strategi monitoring yang akan diadopsi di sekolah harus mengacu pada implementasi kebijakan belajar-mengajar dan memperhatikan kualitas monitoring.

\section{Pola Desain Kurikulum Pendidikan Agama Islam}

Beberapa ahli merumuskan macam-macam desain kurikulum. Eisner dan Vallance (1974) membagi desain menjadi lima jenis, yaitu model pengembangan proses kognitif, kurikulum sebagai teknologi, kurikulum aktualisasi diri, kurikulum rekonstruksi sosial, dan kurikulum rasionalis akademis. McNeil (1977) membagi desain kurikulum menjadi empat model, yaitu 
model kurikulum humanistis, kurikulum rekonstruksi sosial, kurikulum teknologi, dan kurikulum subjek akademik. Saylor, Alexander, dan Lewis (1981) membagi desain kurikulum menjadi kurikulum subject matter disiplin, kompetensi yang bersifat spesifik atau kurikulum teknologi, kurikulum sebagai proses, kurikulum sebagai fungsi sosial, dan kurikulum yang bersifat individu. Brennan (1985) mengembangkan tiga jenis model desain kurikulum, yaitu kurikulum yang berorientasi pada tujuan, model proses, dan model kurikulum yang didasarkan kepada analisis situasional. Longstreet dan Shane (1993) membagi desain kurikulum menjadi empat desain, yaitu kurikulum yang berorientasi pada masyarakat, desain kurikulum yang berorientasi pada anak, kurikulum yang berorientasi pada masyarakat, dan desain kurikulum yang bersifat eklektik (Sanjaya, 2010, p.63).

Manakala kita kaji desain kurikulum yang dikemukakan para ahli tersebut, kurikulum itu memiliki kesamaan-kesamaan sebagaimana skema berikut:

\begin{tabular}{|c|c|c|c|c|c|}
\hline \multicolumn{6}{|c|}{ PAKAR KURIKULUM } \\
\hline $\begin{array}{l}\text { Sukmadin } \\
\text { ata }\end{array}$ & $\begin{array}{l}\text { Eisner \& } \\
\text { Vallance } \\
(1974)\end{array}$ & $\begin{array}{l}\text { McNeil } \\
(1977)\end{array}$ & $\begin{array}{l}\text { Saylor, } \\
\text { Alexander, } \\
\text { dan Lewis } \\
(1981)\end{array}$ & $\begin{array}{l}\text { Brennan } \\
(1985)\end{array}$ & $\begin{array}{l}\text { Longstreet \& } \\
\text { Shane (1993) }\end{array}$ \\
\hline \multirow{3}{*}{$\begin{array}{l}\text { Subject } \\
\text { centered } \\
\text { design }\end{array}$} & $\begin{array}{l}\text { Pengemba } \\
\text { ngan } \\
\text { proses } \\
\text { kognitif }\end{array}$ & $\begin{array}{l}\text { Kurikulum } \\
\text { subjek } \\
\text { akademik }\end{array}$ & $\begin{array}{l}\text { Subject } \\
\text { matter } \\
\text { disiplin }\end{array}$ & $\begin{array}{l}\text { Kurikulum } \\
\text { berorientasi } \\
\text { pada tujuan }\end{array}$ & $\begin{array}{l}\text { Kurikulum } \\
\text { berorientasi } \\
\text { pada } \\
\text { pengetahuan }\end{array}$ \\
\hline & $\begin{array}{l}\text { Kurikulum } \\
\text { sebagai } \\
\text { teknologi }\end{array}$ & $\begin{array}{l}\text { Kurikulum } \\
\text { teknologi }\end{array}$ & $\begin{array}{l}\text { Kurikulum } \\
\text { teknologi }\end{array}$ & $\begin{array}{l}\text { Kurikulum } \\
\text { berorientasi } \\
\text { pada proses }\end{array}$ & \\
\hline & $\begin{array}{l}\text { Kurikulum } \\
\text { rasional } \\
\text { akademis }\end{array}$ & & & & \\
\hline $\begin{array}{l}\text { Learner } \\
\text { centered } \\
\text { design }\end{array}$ & $\begin{array}{l}\text { Kurikulum } \\
\text { aktualisasi } \\
\text { diri }\end{array}$ & $\begin{array}{l}\text { Kurikulum } \\
\text { humanis }\end{array}$ & $\begin{array}{l}\text { Kurikulum } \\
\text { yang } \\
\text { bersifat } \\
\text { individu }\end{array}$ & & $\begin{array}{l}\text { Kurikulum } \\
\text { berorientasi } \\
\text { pada anak }\end{array}$ \\
\hline $\begin{array}{l}\text { Problem } \\
\text { centered } \\
\text { design }\end{array}$ & $\begin{array}{l}\text { Kurikulum } \\
\text { rekonstruk } \\
\text { si social }\end{array}$ & $\begin{array}{l}\text { Kurikulum } \\
\text { rekonstruksi } \\
\text { sosial }\end{array}$ & $\begin{array}{l}\text { Kurikulum } \\
\text { sebagai } \\
\text { fungsi } \\
\text { sosial }\end{array}$ & $\begin{array}{l}\text { Kurikulum } \\
\text { berorientasi } \\
\text { pada } \\
\text { analisis } \\
\text { situasional }\end{array}$ & $\begin{array}{l}\text { Kurikulum } \\
\text { berorientasi } \\
\text { pada } \\
\text { masyarakat }\end{array}$ \\
\hline
\end{tabular}

Tabel: Para Ahli 


\section{Desain Pengembangan Kurikulum}

Pendidikan Agama Islam

Selanjutnya, berdasarkan pada apa yang menjadi fokus pengajaran, desain kurikulum Pendidikan Agama Islam, maka pembahasan makalah akan membahas tentang desain kurikulum menurut Sukmadinata, yaitu:

\section{Subject centered design}

Subject centered design curriculum merupakan kurikulum yang dipusatkan pada isi atau materi yang akan diajarkan. Desain ini merupakan bentuk desain yang paling banyak digunakan. Desain ini juga disebut sebagai separated subject curriculum, karena kurikulum model ini tersusun atas sejumlah mata pelajaran dan diajarkan secara terpisahpisah (Nana S. Sukmadinata, 2007, p. 113-114).

Beberapa variasi model ini antara lain:

a. The subject design

Ciri variasi model ini yaitu:

1) Materi pelajaran disajikan secara terpisah-pisah dalam bentuk mata-mata pelajaran;

2) Isi pelajaran diambil dari pengetahuan dan nilai-nilai yang telah ditemukan oleh ahliahli sebelumnya;

3) Siswa dituntut menguasai semua pengetahuan yang diberikan;

4) Tidak jarang siswa menguasai bahan hanya pada tahap hafalan, bahan dikuasai secara verbalitas (Nana S. Sukmadinata, 2007, p.114). The disclipines design

Ciri dari variasi model kurikulum ini antara lain:

1) Menekankan pada isi atau materi kurikulum;

2) Kriteria (tentang apa yang disebut subject/ilmu) telah tegas;

3) Isi kurikulum yang diberikan di sekolah adalah disiplin-disiplin ilmu;

4) Peserta didik didorong untuk memahami logika atau struktur dasar suatu disiplin, memahami konsep-konsep, ide-ide dan prinsip-prinsip penting, juga didorong utuk memahami cara mencari dan menemukan;

5) Proses belajar menggunakan pendekatan inkuiri dan discovery (Nana S. Sukmadinata, 2007, p.116).

Penggunaan dua pola desain kurikulum di atas sedikit sekali mendapat proporsi dalam kurikulum Pendidikan Agama Islam karena desain ini masih dalam taraf pemula atau taraf verbalistik untuk peserta didik tingkat dasar (ibtida') dan kurang sesuai untuk tingkat berikutnya. 


\section{Mahrus}

b. The broad fields design

Dalam model ini mereka menyatukan beberapa mata pelajaran yang berdekatan atau berhubungan menjadi satu bidang studi seperti Sejarah, Geografi, dan Ekonomi digabung menjadi Ilmu Pengetahuan Sosial (Nana S. Sukmadinata, 2007, p.116-117), ilmu nahwu, ilmu sharaf, ilmu balaghah, ilmu mantiq, ilmu 'arudh dikelompokkan sebagai "ilmu alat", dan sebagainya (Mujib, dkk. 2006, p.160).

Pola desain kurikulum ini lebih baik diterapkan dalam pola pengembangan kurikulum Pendidikan Agama Islam dari pada kedua pola sebelumnya. Walaupun demikian, pola ini masih belum memenuhi kriteria kaffah yang dapat menyangkut semua masalah kehidupan peserta didik, orang tua, dan masyarakat. Misalnya, interpretasi tentang tafsir hanya menggunakan ilmu bantu "kebahasaan, asbabun nuzul, qishah israiliyah, dan ushul fiqh", belum menggunakan interpretasi yang aktual dan kontekstual yang menuntut adanya pemasukan materi ekonomi, politik, social, biologis, psikologis, dan sebagainya. Dengan demikian, hasil interpretasi umat Islam dari Al-Qur'an atau AsSunnah belum memenuhi kebutuhan yang diinginkan karena hanya bersifat normatif. Firman Alloh QS. Al-Baqarah (2): 8, yang berarti sebagai berikut:

Artinya: "Apakah kamu beriman kepada sebagian kitab dan ingkar terhadap sebahagian yang lain? (QS. Al-Baqarah: 8)."

Ayat ini mengisyaratkan adanya keutuhan dalam memahami dan menerapkan sesuatu, tanpa ada yang diabaikan. Semua merupakan sistem yang komponennya saling mengait, dan keberartian satu sangat tergantung pada keberartian yang lain.

\section{Learner centered design}

Learner centered design curriculum merupakan kurikulum yang memberikan tempat utama kepada peserta didik. Guru hanya berperan menciptakan situasi belajar-mengajar, mendorong dan memberikan bimbingan sesuai dengan kebutuhan peserta didik.

Ada dua ciri utama yang membedakan desain model learner centered design dengan subject centered design. Pertama, learner centered design mengembangkan kurikulum dengan bertolak dari peserta didik dan bukan dari isi. Kedua, learner centered design bersifat not-preplaned (kurikulum yang tidak terorganisasikan sebelumnya) tetapi dikembangkan bersama antara guru dengan siswa dalam penyelesaian tugas-tugas pendidikan. Organisasi kurikulum didasarkan atas masalah-masalah atau topik-topik yang 
menarik perhatian dan dibutuhkan peserta didik serta disesuaikan dengan tingkat perkembangan mereka.

Salah satu variasi model ini adalah the activity or experience design. Ciri dari variasi model ini adalah:

a. Struktur kurikulum ditentukan oleh kebutuhan dan minat peserta didik dan implementasinya hendaknya guru dapat menemukan minat dan kebutuhan peserta didik dan membantu para siswa memilih mana yang paling penting dan urgen;

b. Kurikulum disusun bersama oleh guru dan para siswa;

c. Desain kurikulum menekankan pada pemecahan masalah (Nana S. Sukmadinata, 2007, p.118).

\section{Problems centered design}

Problems centered design berdasar pada filsafat yang mengutamakan peranan manusia dan menekankan manusia dalam kesatuan kelompok yaitu kesejahteraan masyarakat. Konsep ini beradasar dari asumsi bahwa manusia sebagai makhluk sosial selalu hidup bersama. Manusia menghadapi masalah bersama dan dipecahkan bersama pula. Model ini menekankan pada isi maupun perkembangan peserta didik.

Variasi model ini antara lain:

\section{a. The areas of living design}

Model ini menekankan prosedur belajar melalui pemacahan masalah dan ciri lain model ini adalah menggunakan pengalaman dan situasi-situasi nyata dari peserta didik sebagai pembuka jalan dalam mempelajari bidang-bidang kehidupan. Desain ini menarik minat peserta didik dan mendekatkannya pada pemenuhan kebutuhan hidupnya dalam bermasyarakat (Nana S. Sukmadinata, 2007, p.120). The core design

Istilah the core curriculum merujuk pada suatu rencana yang mengorganisasikan dan mengatur bagian terpenting dari program pendidikan umum di sekolah. Faunce dan Bossing mengistilahkan core curriculum dengan merujuk pada pengalaman belajar berasal dari: 1) kebutuhan atau dorongan secara individual maupun secara umum, dan 2) kebutuhan secara sosial dan sebagai warga Negara masyarakat demokratis (Subandijah, 1993, p.14).

Pada awalnya, core dimaksudkan sebagai bahan penting yang harus diketahui oleh setiap peserta didik pada semua tingkatan sekolah. Jadi, core memberikan pendidikan 


\section{Mahrus}

umum yang mana materinya perlu diketahui atau dipelajari setiap anak didik (Nana S. Sukmadinata, 2007, p.150).

Terdapat banyak vasiasi pandangan tentang the core design. Mayoritas memandang the core curriculum sebagai suatu model pendidikan atau program pendidikan yang memberikan pendidikan umum. The core curriculum diberikan guru-guru yang memiliki penguasaan dan berwawasan luas, bukan spesialis. Variasi the core curriculum menurut Alberty ada enam, yaitu:

1) The separate subject core, yaitu core yang terdiri dari sejumlah mata pelajaran yang diorganisasikan, diajarkan secara bebas untuk menunjukkan hubungan masingmasing pelajaran tersebut;

2) The correlated core, yaitu core yang terdiri dari sejumlah mata pelajaran yang dihubungan antara yang satu dengan yang lain;

3) The fused core, yaitu core yang terdiri dari masalah yang luas, unit kerja atau tema yang disatukan, yang dipilih untuk menghasilkan arti mengajar secara tepat dan efektif mengenai isi pelajaran tertentu, misalnya Matematika, IPA, dan IPS;

4) The activity core, yaitu core yang menampakkan mata pelajaran yag dilebur dan diintegrasikan;

5) The areas of living core, yaitu core yang merupakan masalah luas yang dapat memenuhi kebutuhan fisik dan sosial, serta masalah minat peserta didik;

6) The social problems core, yaitu core merupakan unit kerja yang direncanakan oleh peserta didik dan guru untuk memenuhi kebutuhan kelompok (Nana S. Sukmadinata, 2007, p.151).

Masing-masing desain tersebut dikembangkan menjadi suatu rancangan kurikulum yang memuat unsur-unsur pokok kurikulum, yaitu tujuan, isi, pengalaman belajar, dan evaluasi, yang sesuai dengan inti setiap model desain.

\section{Desain Pengembangan Kurikulum Pendidikan Islam}

Desain kurikulum dapat didefinisikan sebagai rencana atau susunan dari unsur-unsur pokok kurikulum yang terdiri atas tujuan, isi, pengalaman belajar, dan evaluasi, yang sesuai dengan inti setiap model desain. Begitu juga dalam mendesain kurikulum pendidikan agama Islam harus memuat dari unsur-unsur pokok kurikulum. 


\section{Desain Pengembangan Kurikulum}

Pendidikan Agama Islam

Pendidikan agama Islam yang sedang dilaksanakan dalam banyak lembaga pendidikan formal belum sesuai dengan tujuan pendidikan sebagaimanayang tercantum dalam UndangUndang Sistem Pendidikan Nasional (UU SISDIKNAS) No. 20 Tahun Azizy .2003 menambahkan bahwa kegagalan ini berimbas pada masalah degradasi moral (Qodri Azizy, 2003, p.93).

Husni Rahim melihat faktor kegagalan pendidikan agama Islam di negara kita dari segi kurikulum. Dari segi ini materi pendidikan agama Islam di sekolahterlalu akademis, terlalu banyak topik, banyak pengulangan yang tidak perlu, tidak memperhatikan aspek afektif karena hanya mementingkan aspek kognitif dan metode pengajaran kurang tepat (Husni Rahim, 2001, 105). Faktor lain yang mempengaruhi kegagalan pendidikan agama Islam dan pendidikan secara ,umunya adalah dari factor menejemen, sumberdaya manusiasarana dan prasarana, dualisme penyelenggaraan pendidikan di negara kita dan lain sebaginya yang menuntut segera dicarikan solusi dan mengubah dari segala tantangan di atas menjadi peluang, agar pendidikan di negara kita menjadi berkualitas yang akan berimbas pada kemajuan bangsa dan negara, sebagiamana dinyatakan Fazlurrahman bahwa, setiap reformasi dan pembaharuan dalam Islam harus dimulai dengan pendidikan .

Memperhatikan tuntutan di atas pendidikan agama Islam di madrasah dan sekolahsekolah umum hendaknya diadakan pemikiran ulang dan rekayasa ulang. Salah satunya adalah dengan analisa kebutuhan dalam menejemen pendidikan Analisa kebutuhan disini .agama Islam adalah cara yang efektif untuk mengidentifikasi masalah-masalah yang muncul dalam sebuah organisasi, termasuk juga organisasi .pembelajaran

\section{Berbagai masalah dan tantangan terhadap pendidikan Islam}

Permasalahan besar yang telah lama menjangkit di negara kita antara lain disintegrasi bangsa, tawuran antar suku dan kelompok, pembrontakan, kemiskinan, kebodohan, pengangguran yang pontensi pada kejahatan ditambah adanya krisis moneter tahun 1997 yang sampai kini berkepanjangan. Kondisi demikian memiliki implikasi menurunnya mutu kehidupan masyarakat Indonesia secara umum.

Tantangan terhadap pendidikan agama Islam di antaranya, krisis moral (Qodri Azizy, 2003, p.94). Melalui tayangan acara-acara di media elektronik dan media massa lainnya, yang ,menyuguhkan pergaulan bebas, sex bebas, konsumsi alkohol dan narkotikaperselingkuhan, pornografi, kekerasan, liar dan lain-lain. Hal ini akan berimbas pada if generasi perbuatan negat 


\section{Mahrus}

,muda seperti tawuran, pemerkosaan, hamil di luar nikahpenjambretan, pencopetan, penodongan, pembunuhan oleh pelajar, malas belajar dan tidak punya integritas dan krisis akhlaq lainnya.

Permasalahan selanjutnya adalah krisis kepribadian (Qodri Azizy, 2003, p.96). Dengan kemajuan teknologi dan ilmu pengetahuan di suatu negara yang menyuguhkan kemudahan, kenikmatan dan kemewahan akan menggoda kepribadian seseorang. Nilai kejujuran, kesederhanaan, kesopanan, kepedulian sosial akan terkikis . Oleh karena itu sangat mutlak diperlukan bekal pendidikan agama, agar kelak dewasa akan tidak menjadimanusia yang ,berkepribadian rendah, melakuan korupsi kolusi dan nepotisme, melakukan kejahatan menyerang ,intelektual, merusak alam untuk kepentingan pribadikelompok yang tidak sepaham, percaya perdukunan, menjadi budak setan dan lain-lain.

Faktor pendorong adanya tantangan di atas dikarenakan longgarnya pegangan terhadap $\mathrm{n}$ agama dengan mengedepankan ilmu pengetahuan, kurang efektifnya pembinaamoral yang dilakukan oleh kepala rumah tangga yaitu dengan keteladanan dan pembiasaan, derasnya arus ,informasi budaya negatif global diantaranya, hedonisme lain, -sekulerisme, purnografi dan lain tidak ada tindakan efektif dari pemerintah karena sibuk memikirkan perebutan jabatan .

Dengan demikian pendidikan agama Islam dituntut untuk mampu membekali peserta didik moral, kepribadian, kualitas dan kedewasaan hidup guna menjalani kehidupan bangsa yang ekonomi agar dapat multi cultural, yang sedang dilanda krisishidup damai dalam komunitas dunia

\section{Analisa Kebutuhan Pendidikan Agama Islam dan Aplikasinya}

Sebagaimana yang telah kita ketahui bahwa pendidikan agama Islam di negara kita Untuk .mengalami kegagalan, yang disebabkan karena beberapa faktoritu perlu diadakan analisa kebutuhan guna mengetahui kesenjangan yang perlu dibenahi dan merumuskanlangkah strategis untuk meningkatkan kualitas pendidikan agama Islam.

Masih ada kesenjangan pendidikan agama Islam di sekolah formal selama ngan ini de kondisi yang seharusnya. Hal ini dapat dibuktikan dengan beberapa indikator. Sebagaimana Husni Rahim menyebutkan indikasi itu di antaranya, (1), masih banyak anak yang telah belajar agama selama 12 tahun, tetapi umumnya tidak n dengan baik, (2), mampu membaca al Qur'a tidak menjalankan ibadah dengan baik dan tidak berakhlaq mulia ( tawuran, penyalah gunaan obat, minuman keras, (pergaulan bebas dan tindak asusila, (3), meluasnya KKN (Korupsi, Kolusi 
dan sifat konsumtif, karena gagal dalam Nepotisme) yang disebabkan karena manusia berbelajar agama sehingga mudah tergoda untuk berbuat tidak baik.Mengapa hal ini bisa terjadi, Rahim fakt-memberikan gambaran faktoror penyebabnya diantaranya adalah; materi pendidikan agama ,Islam terlalu akademislalu banyak topik, banyak pengulangan yang tidak perlu, tidak ter memperhatikan aspek afektif karena hanya mementingkan aspek kognitif dan metode pengajaran Al Qur'an tidak tepat (Husni Rahim, 2001, 117).

Hal ini diperjelas dengan pernyataan Muhaimin bahwa kegagalan pendidikan agama setidaknya disebabkan karena mengalami kekurangan dalam dua aspek mendasar, yaitu; (a) pendidikan agama masih berpusat pada hal-hal yang bersifat simbolik, ritualistic serta bersifat an ruh haram) dan kehilang-legal formalistic (halalmoralnya, (b) kegiatan pendidikan agama cenderung bertumpu pada penggarapan ranah kognitif dengan menyampingkan ranah psikomotorik dan afektif (Muhaimin, 2003, 67).

Muhaimin menambahkan bahwa; misalnya materi pendidikan agama Islam di tingkat sub pokok -dasar bersifat serakah, yakni segala macam topic atau subbahasan yang sebenarnya menjadi bagian dari pokok-pokok pembahasan non PAI serta menjadi tugasdan tanggung jawab guru non-PAI harus termuat dalam pelajaran PAI. nya belum waktunya Materi PAI yang sebetul diberikan pada tingkat dasar misalnya haji, zakat mal, sewa, waqaf dan lain-lain diberikan yang akhirnya menjebak guru PAI pada transfer ilmu pengetahuan atau ranah kognitif belaka (Muhaimin, 2003, 68).

Hal ini disebabkan juga karena masih terdapat problematika pengajaran agama Islam baik secara makro maupun mikro. Problematika makro di sini adalah kendala-kendala yang ada hubunganya dengan masalah di luar sekolah menyangkut kebijakan pemerintah mengenai $\mathrm{n}$ problematika pendidikan nasional. Sedangkamikronya adalah menyangkut strategi pembelajaran dan kebijakan dari pimpinan sekolah (Suhadi, 2012).

Sekolah melalui pendidikan agama mestinya dapat menghantarkan para peserta didik persaingan untuk menjadi sumber daya manusia yang unggul dalamhidup di jaman global. Keunggulan sumber daya manusia itu mencakup aspek moral dan ketaqwaan di samping memiliki penguasaan ilmu pengetahuan dan teknologi, keterampilan. Karakter lainnya yang dibutuhkan adalah keuletan, keberanian, dan semangat kebangsaan.

Untuk memenuhi hal di atas maka perlu diadakan kegiatan berupa pengembangan materi pelajaran yang bermuatan keimanan dan ketaqwaan (imtaq) dan ilmu pengetahuan dan teknologi 


\section{Mahrus}

(iptek). Upaya penyusunan bahan ajar yang iptek untuk TK \& RA, SD \& bermuatan imtaq dan \& MI, SLTP \& MTs, dan SMUdiharapkan dapat dijadikan model bagi (12 -MA (TK \& RA guru dan pelaksanapendidikan di lapangan untuk menghasilkan manusia Indonesia yang unggul dan utuh belum sepenuhnya berjalan dengan baik .

Belajar dari pengalaman negara-negara lain dalam menangani tantangan dan krisis serupa, di sana membutuhkan sumber daya manusia yang unggul. Juga belajar dari sejarah masa lalu, bahwa kemajuan yang pernah dicapai oleh para pendahulu kita kap yang karena adanya si mau berubah. Meneladani sikap progresivitas yang ditunjukkan nabi Muhammad dalam mendidik kaumnya dari jahiliyyah menuju masyarakat yang beradab dan maju. Allah juga telah memerintahkan dalam Al qur'an surat al-Ra'd ayat 11:

Artinya: "Dia tidak akan merubah nasib suatu bangsa, sebelum bangsa tersebut mau merubah dirinya sendiri” (QS: al-Ra'd. 11)

Melihat permasalahan di atas maka analisa kebutuhan dapat dilihat secara mikro dan makro dengan penjelasan sebagai berikut ;

(1). Analisa kebutuhan mikro

Menurut Nur Fathoni mengutip I.N Sudana Degeng bahwa analisa kebutuhan dalam kegiatan pembelajaran adalah sebagai berikut (Fathoni, M. Kholid, 2005, p.79):

- Kebutuhan kondisi pembelajaran yang meliputi tujuan, kendala-kendala (keterbatasan materi, keterbatasan waktu, keterbatasan media, keterbatasan personalia, dan keterbatasan dana, juga karakteristik peserta didik).

- Kebutuhan strategi pembelajaran yang meliputi: strategi pengorganisasian , .anpenyampaian pelajaran dan pengelola

- Kebutuhan hasil pembelajaran yang meliputi : efektifitas, efisiensi dan daya .tarik

(2). Analisa kebutuhan makro

- Budgeting dalam system pendidikan nasional, Permasalahan mengenai budgeting masalah adalah masalah yang cukup pelik dan dilematis. Inilahutama yang menjadi rintangan dalam pelaksanaan pendidikan yang maju, adil dan merata.

- Dikotomi lembaga pendidikan nasional. Banyak pakar pendidikan menilai bahwa dikotomi lembaga pengelola pendidikan yang terbagi dalam Departemen Pendidikan Nasional dan Departemen Agama menjadi awal permasalahan pendidikan yang ada dalam penyampaian materi pendidikan keagamaan. Hal inilahyang menghambat proses 
internalisasi pemahaman nilai-nilai keagamaan yang termaktub dalam pendidikan .agama

- Sarana dan prasarana pendidikan yang belum mendukung mengakibatkan banyaknya hambatan yang terjadi pada proses penyampaian, pemahaman dan penyerapan nilai-nilai moral keagamaan.

- Evaluasi menejemen sekolah masih belum optimal (Fathoni, M. Kholid, 2005, p.82).

\section{Pengembangan Kurikulum Pendidikan Agama Islam Dalam Upaya Mengatasi Berbagai Tantangan dan Masalah}

(1). Strategi Pembelajaran

Tujuan pembelajaran agama Islam yang harus dirumuskan dengan bentuk behavioral atau tau bisa diukur. Hal berbentuk tingkah laku dan juga measurable aini membutuhkan strategi pembalajaran yang khusus. Strategi disini adalah suatu kondisi yang diciptakan oleh guru dengan sengaja yang meliputi metode, materi, sarana prasarana, media dan lain sebagainya agar siswa dipermudah dalam mencapai tujuan pembelajaran yang ditetapkan (Azra, Azyumardi, p.73).

(2). Metode Pembelajaran Agama Islam

Pendidikan agama Islam sebenarnya tidak hanya cukup dilakukan dengan pendekatan teknologik karena aspek yang dicapai tidak cukup kognitif tetapi justru lebih dominan yang afektif dan psikomotorik, maka perlu pendekatan yang bersifat nonteknologik. Pembelajaran tentang akidah dan akhlak lebih menonjolkan aspek nilai, baik ketuhanan maupun kemanusiaan yang hendak ditanamkan dan dikembangkan pada diri siswa sehingga dapat melekat menjadi sebuah kepribadian yang mulia. Sehingga menurut Noeng Muhajir dalam bukunya Abudin Nata ada beberapa strategi yang bisa digunakan dalam pembelajaran nilai yaitu : tradisional maksudnya dengan memberikan nasehat dan indoktrinasi, bebas maksudnya siswa diberi kebebasan nilai yang disampaikan, reflektif -maksudnya mondarmandir dari pendekatan teoritik ke empirik, transiternal maksudnya sama terlibat -guru dan siswa samadalam proses komunikasi aktif tidak hanya verbal dan fisik tetapi juga melibatkan komunikasi batin (Abudin Nata, 2003, p.109).

(3). Materi Pembelajaran Agama Islam 


\section{Mahrus}

Disamping perlu adanya reformulasi materi-materi PAI yang selama ini menjebak pada psikomotorik dan ranah kognitif dengan mengabaikan ranakafektif, materi PAI dipandang masih jauh dari pendekatan pendidikan multi kultural, akibatnya masih banyak kerusuhan yang dipicu dari masalah SAR (suku, agama dan ras). Untuk itu materi pendidikan agama hendaknya merupakan sarana yang efektif untuk menginternalisasi nilai-nilai atau aqidah inklusif pada peserta didik. Selain itu, pada masalah-masalah syari'ah pendidikan agama Islam selama ini mencetak umat Islam yang selalu bertengkar antar pengikut madzhab (Sudarsono Sudirjo dkk, 2004, p. 112).

Maka dalam hal ini pendidikan Islam perlu memberikan pelajaran "fiqih muqarran" untuk memberikan penjelasan adanya perbedaan pendapat dalam Islam dan semua pendapat itu sama memiliki argumen, dan wajib bagi kita untuk -samamenghormati. Sekolah tidak menentukan salah satu mazhab yang harus diikuti oleh peseta didik, pilihan mazhab terserah kepada mereka masing-masing.

\section{(4). Sumber Daya Guru Agama}

Pada saat ini ada kecenderungan untuk menunjuk guru sebagai salah satu faktor penyebab nya kualitas lulusan siswa. Kritikan mulai dari ketidak minimefektifnya guru dalam menjalankan tugas, kurangnya motivasi dan etos kerja, sampai kepada ketidak mampuan guru dalam mendidik dan mengajar kepada anak didiknya.

Untuk meningkatkan motivasi dan etos kerja guru maka faktor pemenuhan kebutuhan sangat berpengaruh. Untuk itu bagaimana mengarahkan kekuatan yang ada dalam diri guru untuk mau melakukan tingkat upaya yang tinggi ke arah tujuan yang telah ditetapkan.

Berbicara tentang motivasi tidak lepas kaitannya dengan beberapa pandangan tentang terbentuknya kepribadian manusia melalui proses pola awal terbentuknya motivasi dan beberapa teori kebutuhan manusia. Suparmin mengutip Mc.Cleland yang mengelompokkan kebutuhan manusia kaitannya dengan ngkatan motivasi dalam peni tugasnya sebagai guru adalah; need for achievement/ kebutuhan untuk berprestasi, need for power/ kebutuhan untuk berkuasa, need for affiliation/ kebutuhan untuk berafiliasi . Bila ketiga kebutuhan terpenuhi maka kerja seorang guru akan tumbuh dan motivasi dan etos berkembang sebagimanayang diharapkan (Suparmin, 2004, p.51).

Dengan motivasi dan etos kerja yang tinggi guru agama akhirnya menjadi penggerak penjiwaan dan pengalaman agama yang mencerminkan pribadi yang taqwa, berakhlaq 
mulia, luhur dan menempati perananan suci dalam mengelola kegiatan pembelajaran, maka dibutuhkan guru yang dirumuskan Zakiyah Darajat dan Husni Rahim sebagai berikut : mencintai jabatannya, bersikap adil, sabar tenang, menguasai metode dan kepemimpinan, berwibawa, gembira, manusiawi dan dapat bekerja sama dengan masyarakat (Husni Rahim, p.123).

Dan tentunya juga dibantu guru bidang studi lain dengan menunjukkan keteladanan bagi gi iman siswa sebagai seorang yang beragama yang baik. Apaladan taqwa terhadap Tuhan Yang Maha Esa merupakan prasyarat utama bagi setiap guru, yang secara praktis akan berimplikasi pada keharusan setiap guru nilai akhlak -untuk mengimplementsikan nilai .yang mulia dalam setiap pelajaran

Menurut Muhaimin bila ada peserta didik yang terlibat narkoba misalnya, maka hal itu bukan merupakan kegagalan guru PAI saja, tetapi juga merupakan kegagalan dari guru ,IPA, IPS dan PPKn. Bila ada siswa yang suka hidup borositu juga kegagalan guru ekonomi dan bila siswa suka merusak matematika danlingkungan itu termasuk kegagalan guru IPA dan seterusnya (Muhaimin, 2003, p.71).

(5). Fasilitas dan Media Pengajaran

Salah satu faktor yang dibutuhkan dalam peningkatan mutu pendidikan agama Islam di aat ini adalah : tempat ibadah (masjid atau sekolah formal smusholla), ruang bimbingan dan penyuluhan agama, laboratorium keagamaan dan .computer berbasis internet Laboratorium tidak hanya dibutuhkan untuk pembelajaran ilmu bahasa dan ilmu eksakta ateri pelajaran juga membutuhkan saja, tetapi semua mlaboratorium termsuk pelajaran agama Islam. Di dalam laboratorium akan dilengkapi media-media pembelajaran. Media pembelajaran yang bersifat audio visual sangat penting untuk tercapainya tujuan pembelajaran, karena media pembelajaran ini berfungsi untuk memberikan pengalaman konkret kepada siswa. Bila guru menyampaikan materiagama dengan bermain kata-kata saja maka materi itu bersifat abstrak sama ketika guru di Eropa mengajar bahasa -guru Latin pada abad 17 .

Muhaimin mengusulkan lima cara yang dijadikan dasar pertimbangan dalam pemilihan sarana/ media pembelajaran PAI yaitu; (1) tingkat kecermatan representasi, (2) tingkat interaktif yang ditimbulkan, (3) tingkat kemampuan khusus, (4) tingkat motivasi yang ditimbulkan, (5) tingkat biaya yang diperlukan (Muhaimin, 2003, p.86). 


\section{Mahrus}

\section{(6). Instrumen Penunjang}

Mengingat pendidikan agama Islam adalah pendidikan yang universal maka, dibutuhkan instrument penunjang antara lain : school culture, extra kurikuler keagamaan, tim penggerak proses pendidikan keagamaan (kepala sekolah, dewan, guru, karyawan, komite, masyarakat sekitar, LSM dan alumni) (Abudin Nata, 2005, p.93).

\section{Langkah-Langkah Strategis Menejemen Pendidikan Agama Islam}

Memperhatikan tuntutan era globalisasi di atas pendidikan agama Islam di madrasah dan sekolah-sekolah umum dilaksanakan dengan beberapa strategi di : antaranyaPertama, penyempurnaan kurikulum pendidikan agama agar materi pelajarannya mencapai komposisi yang proporsional dan fungsional tetapi tidak membebani siswa. Kedua, memadukan materi agama dengan materi pendidikan budi pekerti misalnya PPKn atau pelajaran lainya yang terkait hal ini juga dapat mengikis dikotomi ilmu. Ketiga, menciptakan kondisi agamis di lingkungan sekolah (Abudin Nata, 2005, p.146).

Dalam kaitan ini diperlukan adanya serangkaian kegiatan strategis lainnya antara lain: (1) isu sentral yang bermuatan moral dalam masyarakat -mengidentifikasi isuuntuk dijadikan bahan kajian dalam proses pembelajaran di kelas dengan menggunakan metode klarifikasi nilai (2) mengidentifikasi dan menganalisis kebutuhan siswa dalam pembelajaran pendidikan moral agar tercapai moral yang komprehensif yaitu kematangan dalam pengetahuan moral perasaan moral,dan tindakan moral, (3) mengidentifikasi dan menganalisis masalah-masalah dan kendalakendala instruksional yang dihadapi oleh para guru di sekolah dan para orang tua murid di rumah dalam usaha membina perkembangan moral siswa, serta berupaya memformulasikan alternatif pemecahannya,(4) mengidentifikasi dan mengklarifikasi nilai-nilai moral yang inti dan universal yang dapat digunakan sebagai bahan kajain dalam proses pendidikan moral,(5) mengidentifikasi umber lain yang relevan dengan kebutuhan belajar pendidikan moral. Terkait s-sumberdengan pelajaran budi pekerti ini,sebenarnya telah banyak pelajaran yang diajarkan di sekolah yang menitik beratkan pada etika moral dan adab yang santun seperti pendidikan Agama, PPKn dan BK (Bimbingan Konseling) (Abudin Nata, 2005, p.149).

Selanjutnya pengajaran agama Islam diajarkan sebagai perangkat system yang satu sama lain saling terkait dan mendukung yang mencakup : guru agama yang layak dan cocok tidak under qualifiedadanya kerja sama dengan guru mata ,pelajaran lain, profesionalitas pimpinan sekolah, kurikulum yang baik, metode yang tepat di antaranya metode praktek/ role playing , 
,materi pembiasaan, sholat dzuhur berjamaahdan kerjasama kelengkapan sarana dan masjid orang tua tokoh formal, aparat pemerintah (Syamsul Huda, 2015).

Selanjutnya Husni Rahim mengajak pelaku pendidikan agama Islam di sekolah formal untuk mempertegas visi pendidikan Islam dengan cakupan bahwa visi itu sebagai berikut : Karakter Islami yaitu (1) orientasi holistic artinya kesadaran sebagai pribadi muslim di segala situasi dan kondisi terutama di sekolah, dengan menempatkan nilai-nilai spiritual dan lajaran yang transedental dalam pencapaian tujuan pendidikan strategi pembetidak verbalistik sehingga mudah dikembangkan ketrampilan dan wawasannya secara terpadu, (2) populis yaitu Sekolah/ madrasah dilaksanakan dengan semangat yang merakyat, karena manusia membutuhkan persaudaraan, saling kasih dan semangat memberdayakan kaum tertindas berorientasi mutu yaitu dalam dua tataran : proses dan hasil pendidikan (Husni Rahim, p.147).

Selanjutnya Rahim menjelaskan proses tersebut dalam suasana pembelajaran yang aktif rget pembelajaran. Adapun dan dinamis serta konsisiten dengan program dan tahasilnya adalah output yang berkualitas dalam kognitif, afektif dan psikomotorik dan pluralis pada lembaga pendidikan Islam yang harus tercermin dalam kurikulum dan proses pendidikan guna mewujudkan cita-cita umat Islam Indonesia menjadi ulama yang cendikia atau cendikia yang ulama (Husni Rahim, p.150). 


\section{Mahrus}

\section{Daftar Rujukan}

Azizy, Qodri, 2003. Pendidikan (Agama) Untuk Membangun Etika Sosial. Semarang: CV Aneka Ilmu

Azra, Azyumardi, 1999. Pendidikan Islam ; Tradisi dan Modernisasi Menuju Melenium Baru. Jakarta: Logos

Fathoni, M. Kholid, 2005. Pendidikan Islam dan Pendidikan Nasional Paradigma Baru. Jakarta: Depag RI

Hamalik, Oemar, 2006. Manajemen Pengembangan Kurikulum. Bandung: UPI kerjasama dengan Rosda Karya

Muhaimin, 2003, Arah Baru Pengembangan Pendidikan Islam. Bandung: Nuansa

Mujib, Abdul, dkk. 2006. Ilmu Pendidikan Islam. Jakarta: Kencana

Nata, Abudin, 2005. Pendidikan Islam di Era Global. Jakarta: UIN Jakarta Press

Nata, Abudin, 2003. Manajemen Pendidikan, Mengatasi Kelemahan Pendidikan Islam Di Indonesia. Jakarta: Prenada Media

Rahim, Husni, 2001. Arah Baru Pendidikan Islam di Indonesia, Jakarta: Logos Wacana Ilmu

Sanjaya, Wina. 2010. Kurikulum dan Pembelajaran; Teori dan Praktik Pengembangan

Kurikulum Tingkat Satuan Pendidikan (KTSP). Cet. III. Jakarta: Kencana

Santoso, Subhan Adi, 2017. Implementasi Kurikulum 2013 Dalam Kegiatan Pembelajaran Pendidikan Agama Islam Di Sekolah Menengah Kejuruan Negeri 13 Malang. Jurnal Annaba: Vol. 3 No. 1. 2017

Sudirjo, Sudarsono dkk, 2004. Media Pembelajaran Sebagai Pilihan Dalam Strategi Pembelajaran, Dalam Mozaik Teknologi Pendidikan. Jakarta: Prenada Media

Suhadi, 2012. Teori Kebutuhan Pendidikan di Indonesia http://suhadinet. wordpress.com

Suparmin, 2004. Motivasi dan Etos Kerja. Jakarta: Depag RI

Syamsul Huda, 2015. Pendekatan Penanaman Nilai Pendidikan, http://syamsulberau. wordpress.com/2015/03/12/pendekatan penanaman-nilai-pendidikan 